\title{
Induction of action-at-a-distance mutagenesis by 8-oxo-7,8-dihydroguanine in DNA pol $\lambda$-knockdown cells
}

Hiroyuki Kamiya ${ }^{1,2,3^{*}}$, Masahiro Kurokawa ${ }^{1}$, Tetsuaki Makino ${ }^{1,2}$, Miwako Kobayashi ${ }^{3}$ and Ichiro Matsuoka $^{3}$

\begin{abstract}
Introduction: In DNA, 8-oxo-7,8-dihydroguanine $\left(\mathrm{G}^{\circ}\right.$, 8-hydroxyguanine) is one of the most pivotal oxidatively damaged bases and induces $\mathrm{G}: \mathrm{C} \rightarrow \mathrm{T}: \mathrm{A}$ transversion mutations. DNA polymerase $\lambda$ preferentially inserts $\mathrm{dCTP}$ opposite $\mathrm{G}^{\mathrm{O}}$ in vitro, and this error-free bypass function is considered to be important after $\mathrm{A}$ base removal from $\mathrm{G}^{\mathrm{O}}$ :A pairs by the MUTYH DNA glycosylase. To examine the effects of reduced levels of DNA polymerase $\lambda$ on the $\mathrm{G}^{\mathrm{O}}$-induced mutations, the polymerase was knocked-down in human U2OS cells, and a shuttle plasmid DNA containing a $\mathrm{G}^{\mathrm{O}}: \mathrm{C}$ pair at position 122 in the supF gene was transfected into the cells. The plasmid DNA replicated in the cells was introduced into an Escherichia coli indicator strain, to measure the supF mutant frequency.

Results: The knockdown of DNA polymerase $\lambda$ significantly enhanced the mutant frequency of the $G^{O}$ plasmid DNA. Contrary to our expectations, the knockdown did not promote the targeted G:C $\rightarrow \mathrm{T}: \mathrm{A}$ transversion. Instead, substitution mutations at G:C sites other than position 122 were enhanced in the cells.
\end{abstract}

Conclusions: These results suggested that the knockdown of DNA polymerase $\lambda$ induced action-at-a-distance mutagenesis in human cells when the $\mathrm{G}^{\mathrm{O}} \mathrm{C}$ pair was present in the DNA.

Keywords: 8-Oxo-7,8-dihydroguanine, 8-Hydroxyguanine, DNA polymerase $\lambda$, Knockdown, Action-at-a-distance mutagenesis

\section{Introduction}

Oxidation of DNA and its related compounds by reactive oxygen species (ROS) is considered to cause mutagenesis, carcinogenesis, aging, and neurodegeneration $[1,2]$. ROS are produced by environmental mutagens and carcinogens, as well as endogenously by normal oxygen metabolism, and thus function as enemies from within. Various oxidatively damaged nucleobases are reportedly generated, and 8-oxo-7,8-dihydroguanine $\left(\mathrm{G}^{\mathrm{O}}\right.$, also known as 8-hydroxyguanine) is one of the major damaged bases produced by ROS [3-5]. The $\mathrm{G}^{\mathrm{O}}$ bases are estimated to form in 100-500 residues in DNA per cell per day [6].

\footnotetext{
* Correspondence: hirokam@hiroshima-u.ac.jp

${ }^{1}$ Graduate School of Science and Engineering, Ehime University, 2-5

Bunkyo-cho, Matsuyama 790-8577, Japan

${ }^{2}$ Graduate School of Biomedical and Health Sciences, Hiroshima University,

1-2-3 Kasumi, Minami-ku, Hiroshima 734-8553, Japan

Full list of author information is available at the end of the article
}

The coding potential of this oxidized G base is ambiguous, and both the $\mathrm{A}$ and $\mathrm{C}$ bases have the ability to form pairs with $\mathrm{G}^{\mathrm{O}}$ [7-10]. This nature causes $\mathrm{G}^{\mathrm{O}}$ to be highly mutagenic, and the damaged base induces $\mathrm{G}: \mathrm{C} \rightarrow$ $\mathrm{T}: \mathrm{A}$ and $\mathrm{A}: \mathrm{T} \rightarrow \mathrm{C}: \mathrm{G}$ transversion mutations when it is present in the DNA and the nucleotide pool, respectively, in mammalian cells [11-17]. To suppress the mutations caused by $\mathrm{G}^{\mathrm{O}}$, various DNA repair and nucleotide pool sanitization enzymes exist to remove the damaged base/ nucleotide from the DNA and the nucleotide pool, respectively $[18,19]$.

When dATP is incorporated by DNA polymerases (pols) opposite $\mathrm{G}^{\mathrm{O}}$ in the template DNA, the $\mathrm{G}^{\mathrm{O}}$ :A pair is formed. The mammalian base excision repair enzyme, MUTYH DNA glycosylase, recognizes the $\mathrm{G}^{\mathrm{O}}$ :A pair and removes the unmodified $A$ base from the base pair [20-23]. After the removal of A, the resultant gap is filled by DNA pols. Two X-family DNA pols, DNA pols $\beta$ and $\lambda$, reportedly perform this gap-filling and incorporate $\mathrm{dCTP}$ and dATP opposite $\mathrm{G}^{\mathrm{O}}$ in the gap $[24,25]$. 
DNA pol $\lambda$, one of the translesion synthesis (TLS) DNA pols, is considered to be accurate for the $\mathrm{G}^{\mathrm{O}}$ bypass, and dCTP is preferentially incorporated opposite $\mathrm{G}^{\mathrm{O}}$. Thus, this MUTYH and DNA pol $\lambda$ pathway could prevent the $\mathrm{G}: \mathrm{C} \rightarrow \mathrm{T}: \mathrm{A}$ transversion mutations caused by the oxidized $G$ base. We have examined the effects of knockdowns of various cellular proteins on $\mathrm{G}^{\mathrm{O}}$-induced mutagenesis in human cells [17-19, 26-29]. In cells with knocked-down MUTYH, the G:C $\rightarrow$ T:A transversion mutation induced by a $\mathrm{G}^{\mathrm{O}}: \mathrm{C}$ pair is highly promoted [18]. Therefore, it was expected that similar results would be observed in living human cells with reduced amounts of DNA pol $\lambda$.

In this study, double-stranded plasmid DNA containing the $\mathrm{G}^{\mathrm{O}}: \mathrm{C}$ pair in the supF gene was transfected into human U2OS cells, in which DNA pol $\lambda$ was knockeddown. The DNA pol $\lambda$ knockdown expectedly increased the supF mutant frequency when the $\mathrm{G}^{\mathrm{O}}: \mathrm{C}$ plasmid DNA was introduced. However, the knockdown had no influence on the $\mathrm{G}: \mathrm{C} \rightarrow \mathrm{T}: \mathrm{A}$ transversion frequency, but remarkably enhanced the base-substitution mutations at untargeted G:C sites. These results suggested that the reduction of DNA pol $\lambda$ unexpectedly induces action-at-adistance mutagenesis by $\mathrm{G}^{\mathrm{O}}: \mathrm{C}$ in human cells.

\section{Materials and methods \\ Materials}

Oligodeoxyribonucleotides (ODNs) containing $\mathrm{G}^{\mathrm{O}}$ and G $\left(\mathrm{G}^{\mathrm{O}}\right.$-122, 5'-dCGACTTCGAAGG ${ }^{\mathrm{O}}$ TTCGAATC-3'; G-122, 5' -dCGACTTCGAAGGTTCGAATCC-3'), chemically phosphorylated at their $5^{\prime}$-end on the support during synthesis, were purchased from Nihon BioService (Asaka, Japan) and were purified by HPLC, as described previously $[18,30]$. Other ODNs were obtained from Hokkaido System Science (Sapporo, Japan) and Sigma Genosys Japan (Ishikari, Japan) in purified forms. siRNAs ("stealth RNAi", Life Technologies, Carlsbad, California, USA) were designed according to the BLOCK-iT RNAi Designer software, on the supplier's Web site. The following siRNAs were used: pol $\lambda$ sense, $5^{\prime}$-AAUAGAAG CAUCCUGCUCUGCCUUG-3'; and pol $\lambda$ antisense, 5'-CAAGGCAGAGCAGgaugCUUCUAUU-3'. Stealth RNAi Negative Control Medium GC duplex (\%GC 48, Life Technologies) was used as the negative control.

The Escherichia coli strain KS40/pOF105 was provided by Professor Tatsuo Nunoshiba of International Christian University, and was used as an indicator strain of the $\operatorname{supF}$ mutants [31].

\section{Construction of plasmid DNA containing $\mathrm{G}^{\circ}$ and $\mathrm{G}$}

The double-stranded $\mathrm{G}^{\mathrm{O}}$ and control plasmid DNAs were constructed from the single-stranded forms of pZ189-107 K/402E, and the $\mathrm{G}^{\mathrm{O}}-122$ and G-122 ODNs, respectively, as described [32, 33].

\section{Mutagenesis experiments}

The siRNA was introduced into U2OS cells with cationic liposomes as described [18]. The plasmid DNAs containing a single $\mathrm{G}: \mathrm{C}$ or $\mathrm{G}^{\mathrm{O}}: \mathrm{C}$ pair at position 122 of the supF gene were transfected into the U2OS cells by lipofection, at $24 \mathrm{~h}$ after the siRNA treatment. The transfected cells were cultured for $48 \mathrm{~h}$, and the replicated DNA was recovered from the cells. The DNA was then introduced into the indicator KS40/pOF105 E. coli strain by electroporation, after the unreplicated DNA was removed by Dpn I treatment [31]. The electroporation experiments were repeated several times in single transfection experiments, and the transfection into U2OS cells was independently conducted three $(\mathrm{G}: \mathrm{C})$ and four $\left(\mathrm{G}^{\mathrm{O}}: \mathrm{C}\right)$ times. The supF mutant frequencies were calculated as the ratios of white and faint blue colonies resistant to nalidixic acid and streptomycin.

\section{Western blotting}

The western blotting was performed essentially as described [29]. The cell extracts were prepared with radio immuno-precipitation assay (RIPA) buffer containing protease inhibitors and were fractionated on an SDSpolyacrylamide gel. After transfer, the PVDF membranes were blocked in $3 \%$ nonfat milk and probed with a rabbit anti-DNA pol $\lambda$ antibody (catalogue no. A301-640A, Bethyl Laboratories, Montgomery, Texas, USA) or rabbit anti-GAPDH antibody (catalogue no. G9545, SigmaAldrich, St. Louis, Missouri, USA) for $1 \mathrm{~h}$ in Tris-buffered saline (TBS), containing $0.1 \%$ Tween 20 and $3 \%$ nonfat milk, at $20{ }^{\circ} \mathrm{C}$. After washes, the membranes were incubated with horseradish peroxidase-conjugated anti-rabbit IgG (catalogue no. 7074S, Cell Signaling Technology, Danvers, Massachusetts, USA) for $1 \mathrm{~h}$ in TBS containing $0.1 \%$ Tween 20 and $3 \%$ nonfat milk, at $20{ }^{\circ} \mathrm{C}$. After washes, the proteins were then visualized using the Enhanced Chemiluminescence (ECL) System (GE Healthcare Bio-Sciences, Piscataway, New Jersey, USA) and detected with an LAS 3000 Luminescent Image Analyzer (Fujifilm, Tokyo, Japan).

\section{Statistical analysis}

Statistical significance was examined by the Student's $t$-test. Levels of $P<0.05$ were considered to be significant.

\section{Results}

The DNA pol $\lambda$ knockdown enhanced the mutation frequency of $\mathrm{G}^{\mathrm{O}}: \mathrm{C}$

We examined the effects of the knockdown of DNA pol $\lambda$ by siRNA on the mutations induced by $\mathrm{G}^{\mathrm{O}}$. First, human U2OS cells were treated with the siRNA against this TLS DNA pol, and the knockdown was confirmed by western blotting using an anti-DNA pol $\lambda$ antibody at $24 \mathrm{~h}$ post siRNA introduction (Fig. 1). The knockdown 


\section{control si-pol $\lambda$}

\section{DNA pol $\lambda$}

\section{GAPDH}

Fig. 1 The levels of DNA pol $\lambda$ expression in U2OS cells at $24 \mathrm{~h}$ after siRNA introduction, detected by western blot analysis

efficiency was calculated to be $34 \%$ at $24 \mathrm{~h}$ after siRNA introduction.

Next, we transfected the plasmid DNAs containing a single $\mathrm{G}: \mathrm{C}$ or $\mathrm{G}^{\mathrm{O}}: \mathrm{C}$ pair at position 122 of the supF gene into the U2OS cells, after the siRNA treatment. The supF mutant frequencies were similar when the G:C plasmid was introduced into the cells treated with the siRNA against DNA pol $\lambda$ and the control siRNA $\left(\sim 0.6 \times 10^{-3}\right.$, Fig. 2 , open columns), indicating that the DNA pol $\lambda$ reduction did not affect the background mutant frequency. The supF mutant frequency was $1.7 \times 10^{-3}$ when the plasmid DNA with $\mathrm{G}^{\mathrm{O}}: \mathrm{C}$ was introduced into the control siRNA-treated U2OS cells (Fig. 2). The mutant frequency was $2.2 \times 10^{-3}$, representing a 1.3 -fold (or $0.5 \times 10^{-3}$ ) increase, when DNA pol $\lambda$ was knocked-down (Fig. 2). These results suggested that DNA pol $\lambda$ suppresses the mutagenesis caused by $\mathrm{G}^{\mathrm{O}}$.

The DNA pol $\lambda$ knockdown induced action-at-a-distance mutations

DNA pol $\lambda$ has been implicated as one of the DNA pols that fill the gap in an error-free manner, after MUTYH removes adenine opposite $\mathrm{G}^{\mathrm{O}}$. Thus, we expected that the enhanced mutant frequency in the knockdown cells was due to increased G:C $\rightarrow$ T:A mutations at the target site, as MUTYH was knocked-down [18]. Therefore, we sequenced the supF genes from the colonies on the selection agar plates. Table 1 shows all of the mutations detected in the colonies obtained in this study. We analyzed 68 and 74 colonies derived from the $\mathrm{G}^{\mathrm{O}}: \mathrm{C}$ plasmid DNA in the control and knockdown experiments, respectively. The spectra of the mutations found in the supF gene are summarized in Table 2.

As observed in previous studies, the $\mathrm{G}: \mathrm{C} \rightarrow \mathrm{T}: \mathrm{A}$ transversion at position 122 (the modified site) was most frequently found in the colonies obtained from cells treated with the control siRNA and the $\mathrm{G}^{\mathrm{O}}: \mathrm{C}$ plasmid $[18,26,27]$. The ratio of the targeted $\mathrm{G}: \mathrm{C} \rightarrow \mathrm{T}: \mathrm{A}$ transversion was high, at $56 \%$ (Table 2). In contrast to our initial expectation, however, the ratio of the targeted $\mathrm{G}: \mathrm{C} \rightarrow \mathrm{T}: \mathrm{A}$ mutation decreased to $42 \%$ for the DNA pol $\lambda$-knockdown cells (Table 2), although the total mutant frequency was $0.5 \times 10^{-3}$ higher in the knockdown cells than in the control cells. We then calculated the frequencies of the targeted $\mathrm{G}: \mathrm{C} \rightarrow \mathrm{T}: \mathrm{A}$ transversion, by multiplying the total $\sup F$ mutant frequencies by the percentages of the targeted $\mathrm{G}: \mathrm{C} \rightarrow \mathrm{T}: \mathrm{A}$ mutation. The calculated $\mathrm{G}: \mathrm{C} \rightarrow \mathrm{T}: \mathrm{A}$ frequencies were 1.0 and $0.9 \times 10^{-3}$ in the control and DNA pol $\lambda$ experiments, respectively, indicating that the DNA pol $\lambda$ knockdown did not promote the targeted mutation. Thus, the observed $0.5 \times 10^{-3}$ higher total mutant frequency was due to other mutations.

We noticed that substitution mutations at $\mathrm{G}: \mathrm{C}$ sites $(\mathrm{G}: \mathrm{C} \rightarrow \mathrm{A}: \mathrm{T}, \mathrm{G}: \mathrm{C} \rightarrow \mathrm{T}: \mathrm{A}$, and $\mathrm{G}: \mathrm{C} \rightarrow \mathrm{C}: \mathrm{G}$ mutations) other than position 122 were frequently found (Table 2 ). The ratios of the untargeted substitutions at G:C sites were $44 \%$ (30 mutations for the 68 colonies analyzed) and $61 \%$ (45 mutations for the 74 colonies analyzed) in the control and DNA pol $\lambda$-knockdown cells, respectively. In the knockdown cells, the untargeted substitution mutations at

\section{sup $F$ mutant frequency $\left(\times 10^{-3}\right)$}



Fig. 2 Effects of the DNA pol $\lambda$ knockdown in U2OS cells on the mutant frequency induced by $\mathrm{G}^{\mathrm{O}}$ :C. Open columns, control plasmid containing $\mathrm{G}: \mathrm{C}$ at position 122 ; closed columns, plasmid containing $\mathrm{G}^{\mathrm{O}}: \mathrm{C}$ at position 122 . Transfection experiments were performed three $(\mathrm{G}: \mathrm{C})$ and four $\left(\mathrm{G}^{\mathrm{O}}: \mathrm{C}\right)$ times. Data are expressed as the means + standard errors. ${ }^{*} P<0.05$ vs. control siRNA 
Table 1 Mutations detected in the supF gene ${ }^{a}$

\begin{tabular}{|c|c|c|c|}
\hline \multicolumn{4}{|c|}{$G: C$} \\
\hline control & & si-pol $\lambda$ & \\
\hline $74 \mathrm{~A}->\mathrm{G}$ & 1 & $91 \mathrm{G}->\mathrm{A}$ & 1 \\
\hline $95 \mathrm{C}->\mathrm{G}$ & 2 & $91 \mathrm{G}->\mathrm{C}$ & 1 \\
\hline $98 \mathrm{~A}->\mathrm{G}$ & 1 & $95 \mathrm{C}->\mathrm{G}$ & 1 \\
\hline $101 C->A$ & 1 & $96 \mathrm{~T}->\mathrm{G}$ & 1 \\
\hline $117 \mathrm{C}->\mathrm{T}$ & 3 & $101 C->T$ & 1 \\
\hline $120 \mathrm{~A}->\mathrm{G}$ & 1 & $101 C->A$ & 2 \\
\hline $121 \mathrm{G}->\mathrm{T}$ & 1 & $108 \mathrm{C}->\mathrm{T}$ & 1 \\
\hline $130 C->T$ & 1 & $117 C->T$ & 1 \\
\hline \multirow[t]{6}{*}{ large deletion } & 9 & $118 \mathrm{G}->\mathrm{A}$ & 2 \\
\hline & & $119 \mathrm{~A}->\Delta$ & 1 \\
\hline & & $125 \mathrm{C}->\mathrm{T}$ & 1 \\
\hline & & $126 \mathrm{G}->\mathrm{T}$ & 1 \\
\hline & & large insertion & 1 \\
\hline & & large deletion & 4 \\
\hline \multirow[t]{2}{*}{ total colonies analyzed } & 20 & total colonies analyzed & 19 \\
\hline & $\mathrm{G}^{\mathrm{O}}$ & & \\
\hline control & & si-pol $\lambda$ & \\
\hline $27 \mathrm{G}->A$ & 1 & $61 \mathrm{G}->\mathrm{A}$ & 2 \\
\hline $61 \mathrm{G}->\mathrm{A}, 95 \mathrm{C}->\mathrm{G}, 111 \mathrm{C}->\mathrm{T}, 130 \mathrm{C}->\mathrm{A}, 153 \mathrm{C}->\mathrm{T}$ & 1 & $61 \mathrm{G}->\mathrm{A}, 130 \mathrm{C}->\mathrm{A}$ & 2 \\
\hline $67 \mathrm{G}->\mathrm{A}$ & 2 & $61 \mathrm{G}->\mathrm{A}, 153 \mathrm{C}->\mathrm{T}$ & 1 \\
\hline $72 C->G$ & 1 & $71 C->G$ & 3 \\
\hline $85 G->T$ & 3 & $86 \mathrm{G}->\mathrm{A}$ & 1 \\
\hline $91 \mathrm{G}->\mathrm{C}$ & 1 & $86 \mathrm{G}->\mathrm{A}, 112 \mathrm{G}->\mathrm{A}, 126 \mathrm{G}->\mathrm{C}$ & 2 \\
\hline $95 \mathrm{C}->\mathrm{T}, 122 \mathrm{G}->\mathrm{T}, 125 \mathrm{C}->\mathrm{G}$ & 1 & $91 \mathrm{G}->\mathrm{A}, 122 \mathrm{G}->\mathrm{T}$ & 1 \\
\hline $95 \mathrm{C}->\mathrm{G}$ & 1 & $91 \mathrm{G}->C$ & 2 \\
\hline $101 C->G$ & 1 & $95 \mathrm{C}->\mathrm{G}$ & 2 \\
\hline $107 \mathrm{~T}->\mathrm{G}, 122 \mathrm{G}->\mathrm{T}$ & 1 & $95 \mathrm{C}->\mathrm{G}, 111 \mathrm{C}->\mathrm{T}$ & 1 \\
\hline $112 \mathrm{G}->\mathrm{T}$ & 1 & $101 \mathrm{C}->\mathrm{T}, 122 \mathrm{G}->\mathrm{T}$ & 1 \\
\hline $118 \mathrm{G}->C$ & 4 & $111 C->T, 153 C->T$ & 2 \\
\hline $118 \mathrm{G}->C, 123 \mathrm{~T}->\mathrm{G}$ & 1 & $118 \mathrm{G}->\mathrm{A}$ & 2 \\
\hline $121 \mathrm{G}->\mathrm{T}$ & 5 & $118 \mathrm{G}->C$ & 5 \\
\hline $122 \mathrm{G}->\mathrm{T}$ & 36 & $121 \mathrm{G}->\mathrm{A}$ & 3 \\
\hline $123 \mathrm{~T}->\mathrm{G}$ & 2 & $121 \mathrm{G}->\mathrm{T}$ & 2 \\
\hline $130 \mathrm{C}->\mathrm{T}$ & 2 & $122 \mathrm{G}->\mathrm{A}$ & 3 \\
\hline \multirow[t]{5}{*}{ large deletion } & 4 & $122 \mathrm{G}->\mathrm{T}$ & 29 \\
\hline & & $122 \mathrm{G}->\mathrm{C}$ & 2 \\
\hline & & $126 \mathrm{G}->C$ & 2 \\
\hline & & $130 C->A$ & 1 \\
\hline & & large deletion & 5 \\
\hline total colonies analyzed & 68 & total colonies analyzed & 74 \\
\hline
\end{tabular}


Table 2 Spectra of mutations detected in the supF gene

\begin{tabular}{|c|c|c|c|c|}
\hline & \multicolumn{2}{|l|}{$G: C$} & \multicolumn{2}{|l|}{$\mathrm{G}^{\mathrm{O}}: \mathrm{C}$} \\
\hline & Control & $\overline{\text { si-pol } \lambda}$ & Control & si-pol $\lambda$ \\
\hline \multicolumn{5}{|l|}{ mutations at position 122} \\
\hline$G: C->A: T$ & $0(0)$ & $0(0)$ & $0(0)$ & $3(4)$ \\
\hline$G: C->T: A$ & $0(0)$ & $0(0)$ & $38(56)$ & $31(42)$ \\
\hline$G: C->C: G$ & $0(0)$ & $0(0)$ & $0(0)$ & $2(3)$ \\
\hline \multicolumn{5}{|l|}{ mutations at other positions } \\
\hline \multicolumn{5}{|l|}{ transition } \\
\hline$A: T->G: C$ & $3(15)$ & $0(0)$ & $0(0)$ & $0(0)$ \\
\hline$G: C->A: T$ & $4(20)$ & $7(37)$ & $9(13)$ & $23(31)$ \\
\hline \multicolumn{5}{|l|}{ transversion } \\
\hline$A: T->T: A$ & $0(0)$ & $0(0)$ & $0(0)$ & $0(0)$ \\
\hline$A: T->C: G$ & $0(0)$ & $1(5)$ & $4(6)$ & $0(0)$ \\
\hline$G: C->T: A$ & $2(10)$ & $3(16)$ & $10(15)$ & $5(7)$ \\
\hline$G: C->C: G$ & $2(10)$ & $2(11)$ & $11(16)$ & $17(23)$ \\
\hline small insertion (1-2 bp) & $0(0)$ & $0(0)$ & $0(0)$ & $0(0)$ \\
\hline large insertion (>2 bp) & $0(0)$ & $1(5)$ & $0(0)$ & $0(0)$ \\
\hline small deletion (1-2 bp) & $0(0)$ & $1(5)$ & $0(0)$ & $0(0)$ \\
\hline large deletion (>2 bp) & $9(45)$ & $4(21)$ & $4(6)$ & $5(7)$ \\
\hline others & $0(0)$ & $0(0)$ & $0(0)$ & $0(0)$ \\
\hline total mutations & 20 & 19 & 76 & 86 \\
\hline total colonies analyzed & $20(100)$ & $19(100)$ & $68(100)$ & $74(100)$ \\
\hline
\end{tabular}

$\mathrm{G}: \mathrm{C}$ pairs were more abundant than the targeted $\mathrm{G}: \mathrm{C} \rightarrow$ $\mathrm{T}$ :A transversion. These results were similar to those observed when the Werner syndrome protein (WRN) was knocked-down [29]. We multiplied the total supF mutant frequencies by the percentages of the untargeted substitutions at $\mathrm{G}: \mathrm{C}$ sites for each transfection experiment. The calculated frequencies were $0.6( \pm 0.2)$ and $1.4( \pm 0.3) \times 10^{-3}$ in the control and knockdown cells, respectively (standard errors are shown in parentheses). Thus, the untargeted substitutions were likely to occur by the DNA pol $\lambda$ knockdown, although these values were statistically insignificant $(P=0.10)$. We then examined the mutational patterns in the DNA strand containing the $\mathrm{G}^{\mathrm{O}}$ base (the upper strand of the plasmid) when DNA pol $\lambda$ was knocked-down. Statistical significance was observed, and the untargeted substitution frequencies at the $G$ sites were $0.4( \pm 0.1)$ and $0.8( \pm 0.1) \times 10^{-3}$ in the control and knockdown cells, respectively $(P<0.05)$. Based on these results, we concluded that substitution mutations at $\mathrm{G}$ (or $\mathrm{G}: \mathrm{C}$ ) sites were increased in the DNA pol $\lambda$-knockdown cells. Thus, the $\mathrm{G}^{\mathrm{O}}$ base induced action-at-a-distance mutations when the level of DNA pol $\lambda$ was reduced.

The distributions of the mutations, except for those at the target position, are shown in Fig. $3 b$ for the $\mathrm{G}^{\mathrm{O}}$ experiments. The untargeted mutations were observed in the region from $\sim 60$ bp upstream to $\sim 30$ bp downstream of position 122 , the $\mathrm{G}^{\mathrm{O}}$ site.

\section{Discussion}

The objective of this study was to examine the effects of DNA pol $\lambda$ knockdown on the mutations induced by the $\mathrm{G}^{\mathrm{O}}$ base in DNA. Since DNA pol $\lambda$ is considered to function in an error-free manner when the gap is filled, after MUTYH removes adenine opposite $\mathrm{G}^{\mathrm{O}}$, the reduction of the TLS DNA pol was expected to enhance the $\mathrm{G}: \mathrm{C} \rightarrow \mathrm{T}: \mathrm{A}$ transversion mutation. As shown in Fig. 2, the reduction in the protein level significantly increased the $\mathrm{G}^{\mathrm{O}}$-induced mutations. Unexpectedly, however, sequence analyses indicated that the targeted $\mathrm{G}: \mathrm{C} \rightarrow \mathrm{T}: \mathrm{A}$ mutation was not increased (Table 2). Instead, substitution mutations at $\mathrm{G}: \mathrm{C}$ sites other than the targeted position were frequently found. Thus, DNA pol $\lambda$ may suppress action-at-a-distance mutations in living human cells.

We recently found action-at-a-distance mutations induced by $\mathrm{G}^{\mathrm{O}}$ in cells with knocked-down WRN, although the molecular mechanism(s) of the mutations in the WRN-knockdown cells still remain unknown [29]. Interestingly, Kanagaraj et al. reported that DNA pol $\lambda$ interacted with WRN [34]. They found that WRN physically bound to DNA pol $\lambda$ and enhanced the gap-filling activity of the DNA pol. Moreover, the two proteins reportedly formed nuclear foci induced by oxidative stress, in a DNA replication- and MUTYH-dependent manner. Based on the report by Kanagaraj et al. and our previous and present studies, DNA pol $\lambda$ and WRN could cooperatively prevent the action-at-a-distance mutations. Error-prone DNA pol(s) might be involved in DNA synthesis reactions in DNA regions near the $\mathrm{G}^{\mathrm{O}}$ base upon DNA pol $\lambda$ or WRN reduction. However, as discussed in our previous report [29], this hypothesis is apparently invalid, since mismatch formation by error-prone TLS DNA pols is more likely to occur at A:T sites rather than $\mathrm{G}: \mathrm{C}$ sites [35-39].

We previously suggested some possible reasons for the action-at-a-distance mutations induced by $\mathrm{G}^{\mathrm{O}}$ in the WRN-knockdown cells. The first possibility is the increased mismatch formation generated by the reduction of the $3^{\prime} \rightarrow 5^{\prime}$ WRN exonuclease activity, plus its further inhibition in the presence of the $\mathrm{G}^{\mathrm{O}}$ base [4043]. Alternatively, the formation of $\mathrm{G}^{\mathrm{O}}$ radicals and the following radical cation migration on DNA might cause the action-at-a-distance mutations, because of a prooxidant state in the WRN-reduced cells [44-52]. Although other possibilities are not completely excluded, these explanations are likely to be valid, based on the hypothesis that the inability to interact with WRN is important for the action-at-a-distance mutations in the DNA pol $\lambda$-knockdown cells. Since DNA pol $\lambda$ interacts with WRN, the DNA pol $\lambda$ knockdown 


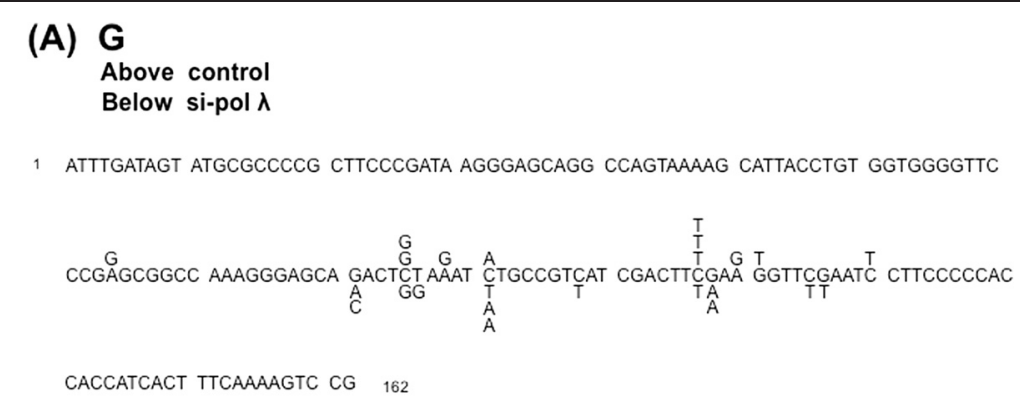

(B) $\mathrm{G}^{0}$

Above control

Below si-pol $\lambda$

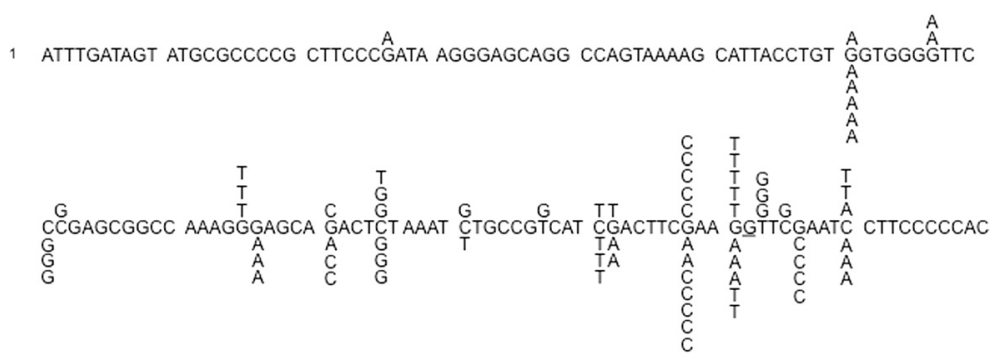

CACCATCACT TTCAAAAGTC CG 162

Fig. 3 Overall distribution of the substitution mutations detected in the supF gene, based on the data shown in Table 1. The sequence of the upper strand of the plasmid is shown. The mutations obtained with the control and anti-pol $\lambda$ siRNAs are shown above and below the sequence, respectively. a The control plasmid containing a G:C pair at position 122. b The plasmid containing a $\mathrm{G}^{\mathrm{O}}: \mathrm{C}$ pair at position 122 . The underlined $\mathrm{G}$ in panel $\mathrm{B}$ represents the $122 \mathrm{nd}$ position, and the targeted mutations are not depicted

might affect the intracellular fate of WRN, including its stability. The effects of DNA pol $\lambda$ knockdown on the WRN protein are currently examined from various viewpoints in our laboratory.

Previously, Efrati et al. reported "action-at-a-distance mutagenesis" in in vitro DNA synthesis reactions conducted by DNA pol $\beta$ when $\mathrm{G}^{\mathrm{O}}$ was present in the template [53]. The authors of the paper observed misincorporation of deoxyribonucleotides opposite the 3 '-base adjacent to the lesion. DNA pol $\beta$ might act in the gap after MUTYH removes adenine opposite $\mathrm{G}^{\mathrm{O}}$ in the DNA pol $\lambda$-knockdown cells more frequently than in the control cells. One may think that similar events contributed to the action-at-a-distance mutagenesis observed in the knockdown cells. However, no mutations were found at position 123 , the $3^{\prime}$-flanking $\mathrm{T}$ base, in the knockdown cells (Fig. 3b, below the sequence). Thus, the misincorporation opposite the 3 '-base adjacent to $G^{\mathrm{O}}$ observed in the in vitro DNA synthesis reactions seemed to play little, if any, roles under our experimental conditions.

The knockdown efficiency of DNA pol $\lambda$ was calculated to be $34 \%$ at $24 \mathrm{~h}$ after siRNA introduction, which was the time point when the plasmid DNAs were transfected (Fig. 1). Since the knockdown promoted the supF mutant frequency, the knockdown with this efficiency certainly affected mutagenesis by the $\mathrm{G}^{\mathrm{O}}$ base (Fig. 2). However, the knockdown efficiency would decrease during $48 \mathrm{~h}$ between the transfection and the plasmid recovery. Thus, more drastic effects could be observed when the knockdown is more effective or when DNA pol $\lambda$-knockout cells are used.

We were able to detect the induction of the action-at-adistance mutagenesis, since we employed the site-directed introduction of the single $\mathrm{G}^{\mathrm{O}}$ base into the shuttle plasmid used for the transfection experiments. Thus, this work confirms that experiments using these types of plasmid DNAs are useful in mutagenesis studies [3].

Pande et al. examined the mutagenesis induced by $\mathrm{G}^{\mathrm{O}}$ in DNA pol $\lambda$-knockdown human cells, using a singlestranded plasmid and ODN hybridization (followed by sequencing) [54]. In agreement with our present finding, no increase in the targeted $\mathrm{G}: \mathrm{C} \rightarrow \mathrm{T}: \mathrm{A}$ transversion was observed. In contrast, the authors did not mention the induction of action-at-a-distance mutations at G/C sites. This discrepancy could be due to the differences in the $\mathrm{G}^{\mathrm{O}}$-DNAs used for the transfection experiments (single-stranded and double-stranded plasmid DNAs) and 
the mutant selection methods (ODN hybridization and phenotypic selection). Thus, our results shown in this study constitute the first evidence that the reduction of DNA pol $\lambda$ resulted in the untargeted mutations by $\mathrm{G}^{\mathrm{O}}$ in human cells.

\section{Conclusions}

In conclusion, action-at-a-distance mutations at G:C (or $\mathrm{G}$ ) sites were induced by $\mathrm{G}^{\mathrm{O}}$ in the DNA pol $\lambda$ knockdown cells. Further studies are necessary to elucidate the detailed mechanism(s) of the untargeted mutagenesis, and are currently in progress.

\section{Abbreviations \\ $\mathrm{G}^{\mathrm{O}}$ : 8-oxo-7,8-dihydroguanine; ODN: Oligodeoxyribonucleotide; pol: Polymerase; ROS: Reactive oxygen species; TLS: Translesion synthesis.}

\section{Competing interests}

The authors declare that they have no competing interests.

\section{Authors' contributions}

HK conceived of the study, and participated in its design and coordination, and drafted the manuscript. MKu performed the mutagenesis studies, the sequence analysis, and the data analysis. TM performed the knockdown experiments and the western blotting. MKo and IM participated in the study design and coordination, and the Western blotting, and helped to draft the manuscript. All authors read and approved the final manuscript.

\section{Acknowledgements}

This work was supported in part by Grants-in-Aid from the Ministry of Education, Culture, Sports, Science and Technology of Japan (20012001 and 25550032), and the Takeda Science Foundation to HK. We thank Dr. Motoshi Suzuki for valuable discussions.

\section{Author details}

${ }^{1}$ Graduate School of Science and Engineering, Ehime University, 2-5 Bunkyo-cho, Matsuyama 790-8577, Japan. ${ }^{2}$ Graduate School of Biomedical and Health Sciences, Hiroshima University, 1-2-3 Kasumi, Minami-ku, Hiroshima 734-8553, Japan. ${ }^{3}$ College of Pharmaceutical Sciences, Matsuyama University, 4-2 Bunkyo-cho, Matsuyama 790-8578, Japan.

Received: 30 April 2015 Accepted: 9 July 2015

Published online: 01 August 2015

\section{References}

1. Halliwell B, Aruoma OI. DNA damage by oxygen-derived species. Its mechanism and measurement in mammalian systems. FEBS Lett. 1991;281:9-19.

2. Ames BN, Shigenaga MK, Hagen TM. Oxidants, antioxidants, and the degenerative diseases of aging. Proc Natl Acad Sci U S A. 1993;90:7915-22.

3. Kamiya H. Mutagenic potentials of damaged nucleic acids produced by reactive oxygen/nitrogen species: approaches using synthetic oligonucleotides and nucleotides: survey and summary. Nucleic Acids Res. 2003;31:517-31.

4. Kamiya H. Mutagenicities of 8-hydroxyguanine and 2-hydroxyadenine produced by reactive oxygen species. Biol Pharm Bull. 2004:27:475-9.

5. Kasai H, Kawai K, Li Y. Analysis of 8-OH-dG and 8-OH-Gua as biomarkers of oxidative stress. Genes Environ. 2008:30:33-40.

6. Lindahl T. Instability and decay of the primary structure of DNA. Nature. 1993;362:709-15.

7. Oda Y, Uesugi S, Ikehara M, Nishimura S, Kawase $Y$, Ishikawa H, et al. NMR studies of a DNA containing 8-hydroxydeoxyguanosine. Nucleic Acids Res. 1991:19:1407-12.

8. Kouchakdjian M, Bodepudi V, Shibutani S, Eisenberg M, Johnson F, Grollman AP, NMR structural studies of the ionizing radiation adduct 7-hydro-8-oxodeoxyguanosine (8-oxo-7H-dG) opposite deoxyadenosine in a DNA duplex. 8-Oxo-7H-dG(syn)-dA(anti) alignment at lesion site. Biochemistry. 1991;30:1403-12.

9. Plum GE, Grollman AP, Johnson F, Breslauer KJ. Influence of the oxidatively damaged adduct 8-oxodeoxyguanosine on the conformation, energetics, and thermodynamic stability of a DNA duplex. Biochemistry. 1995;34:16148-60.

10. Koizume $\mathrm{S}$, Kamiya $H$, Inoue H, Ohtsuka E. Synthesis and thermodynamic stabilities of damaged DNA involving 8-hydroxyguanine (7,8-dihydro-8oxoguanine) in a ras gene fragment. Nucleosides Nucleotides. 1994:13:1517-34.

11. Kamiya H, Miura K, Ishikawa $H$, Inoue H, Nishimura S, Ohtsuka E. c-Ha-ras containing 8-hydroxyguanine at codon 12 induces point mutations at the modified and adjacent positions. Cancer Res. 1992;52:3483-5.

12. Moriya M. Single-stranded shuttle phagemid for mutagenesis studies in mammalian cells: 8-oxoguanine in DNA induces targeted $\mathrm{G} \cdot \mathrm{C} \rightarrow \mathrm{T} \cdot \mathrm{A}$ transversions in simian kidney cells. Proc Natl Acad Sci U S A. 1993;90:1122-6.

13. Kamiya H, Murata-Kamiya N, Koizume S, Inoue H, Nishimura S, Ohtsuka E. 8-Hydroxyguanine (7,8-dihydro-8-oxoguanine) in hot spots of the c-Ha-ras gene: effects of sequence contexts on mutation spectra. Carcinogenesis. 1995;16:883-9.

14. Le Page F, Margot A, Grollman AP, Sarasin A, Gentil A. Mutagenicity of a unique 8-oxoguanine in a human Ha-ras sequence in mammalian cells. Carcinogenesis. 1995;16:2779-84.

15. Tan X, Grollman AP, Shibutani S. Comparison of the mutagenic properties of 8-oxo-7,8-dihydro-2'-deoxyadenosine and 8-oxo-7,8-dihydro-2'deoxyguanosine DNA lesions in mammalian cells. Carcinogenesis. 1999:20:2287-92.

16. Satou K, Kawai K, Kasai H, Harashima H, Kamiya H. Mutagenic effects of 8-hydroxy-dGTP in live mammalian cells. Free Radic Biol Med. 2007:42:1552-60.

17. Satou K, Hori M, Kawai K, Kasai H, Harashima H, Kamiya H. Involvement of specialized DNA polymerases in mutagenesis by 8 -hydroxy-dGTP in human cells. DNA Repair (Amst). 2009;8:637-42.

18. Suzuki T, Harashima $H$, Kamiya $H$. Effects of base excision repair proteins on mutagenesis by 8-oxo-7,8-dihydroguanine (8-hydroxyquanine) paired with cytosine and adenine. DNA Repair (Amst). 2010;9:542-50.

19. Hori M, Satou K, Harashima $H$, Kamiya $H$. Suppression of mutagenesis by 8 -hydroxy-2'-deoxyguanosine $5^{\prime}$-triphosphate

(7,8-dihydro-8-oxo-2'-deoxyguanosine 5'-triphosphate) by human MTH1, MTH2, and NUDT5. Free Radic Biol Med. 2010;48:1197-201.

20. Takao M, Zhang QM, Yonei S, Yasui A. Differential subcellular localization of human MutY homolog (hMYH) and the functional activity of adenine:8-oxoguanine DNA glycosylase. Nucleic Acids Res. 1999:27:3638-44.

21. Slupska MM, Luther WM, Chiang JH, Yang H, Miller JH. Functional expression of hMYH, a human homolog of the Escherichia coli MutY protein. J Bacteriol. 1999;181:6210-3.

22. McGoldrick JP, Yeh YC, Solomon M, Essigmann JM, Lu AL. Characterization of a mammalian homolog of the Escherichia coli MutY mismatch repair protein. Mol Cell Biol. 1995;15:989-96.

23. Ohtsubo T, Nishioka K, Imaiso Y, I wai S, Shimokawa H, Oda H, et al. Identification of human MutY homolog (hMYH) as a repair enzyme for 2-hydroxyadenine in DNA and detection of multiple forms of hMYH located in nuclei and mitochondria. Nucleic Acids Res. 2000;28:1355-64.

24. Maga G, Villani G, Crespan E, Wimmer U, Ferrari E, Bertocci B, 8-Oxo-guanine bypass by human DNA polymerases in the presence of auxiliary proteins. Nature. 2007;447:606-8.

25. Maga G, Crespan E, Wimmer U, van Loon B, Amoroso A, Mondello C, Replication protein $A$ and proliferating cell nuclear antigen coordinate DNA polymerase selection in 8-oxo-guanine repair. Proc Natl Acad Sci U S A. 2008;105:20689-94

26. Kamiya H, Yamaguchi A, Suzuki T, Harashima H. Roles of specialized DNA polymerases in mutagenesis by 8-hydroxyguanine in human cells. Mutat Res. 2010;686:90-5.

27. Kamiya H, Kurokawa M. Mutagenic bypass of 8-oxo-7,8-dihydroguanine (8-hydroxyguanine) by DNA polymerase $\mathrm{k}$ in human cells. Chem Res Toxicol. 2012;25:1771-6.

28. Kamiya $H$, Kurokawa M. DNA polymerase $\lambda$ promotes mutagenesis induced by 8-oxo-7,8-dihydroguanine (8-hydroxyguanine) paired with adenine. Genes Environ. 2013;35:105-9. 
29. Kamiya H, Yamazaki D, Nakamura E, Makino T, Kobayashi M, Matsuoka I, Action-at-a-distance mutagenesis induced by oxidized guanine in Werner syndrome protein-reduced human cells. Chem Res Toxicol. 2015;28:621-8.

30. Kamiya $\mathrm{H}$, Kasai $\mathrm{H}$. Substitution and deletion mutations induced by 2-hydroxyadenine in Escherichia coli: Effects of sequence contexts in leading and lagging strands. Nucleic Acids Res. 1997;25:304-10.

31. Obata F, Nunoshiba T, Hashimoto-Gotoh T, Yamamoto K. An improved system for selection of forward mutations in an Escherichia coli supF gene carried by plasmids. J Radiat Res. 1998;39:263-70.

32. Suzuki T, Harashima H, Kamiya H. Unexpectedly weak impacts of decreased p53 and retinoblastoma protein levels on mutagenesis by 8-oxo-7,8-dihydroguanine (8-hydroxyguanine). Genes Environ. 2011;33:103-8.

33. Tornaletti S, Maeda LS, Kolodner RD, Hanawalt PC. Effect of 8-oxoguanine on transcription elongation by T7 RNA polymerase and mammalian RNA polymerase II. DNA Repair (Amst). 2004;3:483-94.

34. Kanagaraj R, Parasuraman P, Mihaljevic B, van Loon B, Burdova K, König C, Involvement of Werner syndrome protein in MUTYH-mediated repair of oxidative DNA damage. Nucleic Acids Res. 2012;40:8449-59.

35. Matsuda T, Bebenek K, Masutani C, Rogozin IB, Hanaoka F, Kunkel TA. Error rate and specificity of human and murine DNA polymerase $\eta$. J Mol Biol. 2001;312:335-46.

36. Johnson RE, Washington MT, Haracska L, Prakash S, Prakash L. Eukaryotic polymerases I and $\zeta$ act sequentially to bypass DNA lesions. Nature. 2000;406:1015-9.

37. Zhang Y, Yuan F, Xin H, Wu X, Rajpal DK, Yang D, Human DNA polymerase K synthesizes DNA with extraordinarily low fidelity. Nucleic Acids Res. 2000;28:4147-56.

38. Zhong X, Garg P, Stith CM, McElhinny SAN, Kissling GE, Burgers PMJ, The fidelity of DNA synthesis by yeast DNA polymerase zeta alone and with accessory proteins. Nucleic Acids Res. 2006;34:4731-42.

39. Daly J, Bebenek K, Watt DL, Richter K, Jiang C, Zhao M-L, Altered Ig hypermutation pattern and frequency in complementary mouse models of DNA polymerase $\zeta$ activity. J Immunol. 2012;188:5528-37.

40. Harrigan JA, Wilson III DM, Prasad R, Opresko PL, Beck G, May A, The Werner syndrome protein operates in base excision repair and cooperates with DNA polymerase $\beta$. Nucleic Acids Res. 2006;34:745-54.

41. Kamath-Loeb AS, Shen J-C, Schmitt MW, Loeb LA. The Werner syndrome exonuclease facilitates DNA degradation and high fidelity DNA polymerization by human DNA polymerase $\delta$. J Biol Chem. 2012:287:12480-90.

42. Machwe A, Ganunis R, Bohr VA, Orren DK. Selective blockage of the $3^{\prime} \rightarrow 5^{\prime}$ exonuclease activity of WRN protein by certain oxidative modifications and bulky lesions in DNA. Nucleic Acids Res. 2000;28:2762-70.

43. Bukowy Z, Harrigan JA, Ramsden DA, Tudek B, Bohr VA, Stevnsner T. WRN exonuclease activity is blocked by specific oxidatively induced base lesions positioned in either DNA strand. Nucleic Acids Res. 2008;36:4975-87.

44. Pagano G, Zatterale A, Degan P, d'Ischia M, Kelly FJ, Pallardó FV, In vivo prooxidant state in Werner syndrome (WS): Results from three WS patients and two WS heterozygotes. Free Radic Res. 2005;39:529-33.

45. Massip L, Garand C, Turaga RVN, Deschênes F, Thorin E, Lebel M. Increased insulin, triglycerides, reactive oxygen species, and cardiac fibrosis in mice with a mutation in the helicase domain of the Werner syndrome gene homologue. Exp Gerontol. 2006;41:157-68.

46. Goyal RN, Dryhurst G. Redox chemistry of guanine and 8-oxyguanine and a comparison of the peroxidase-catalyzed and electrochemical oxidation of 8-oxyguanine. J Electroanal Chem Interfacial Electrochem. 1982;135:75-91.

47. Yanagawa H, Ogawa Y, Ueno M. Redox ribonucleosides. Isolation and characterization of 5-hydroxyuridine, 8-hydroxyguanosine, and 8hydroxyadenosine from Torula yeast RNA. J Biol Chem. 1992;267:13320-6.

48. Sheu C, Foote CS. Reactivity toward singlet oxygen of a 7,8-dihydro-8-oxoguanosine ("8-hydroxyguanosine") formed by photooxidation of a guanosine derivative. J Am Chem Soc. 1995;117:6439-42.

49. Koizume S, Inoue H, Kamiya H, Ohtsuka E. Novel DNA damage mediated by oxidation of an 8-oxoguanine residue. Chem Commun. 1996;1996:265-6.

50. Koizume S, Inoue $H$, Kamiya H, Ohtsuka E. Neighboring base damage induced by permanganate oxidation of 8-oxoguanine in DNA: involvement of a redox process. Nucleic Acids Res. 1998;26:3599-607.
51. Henderson PT, Jones D, Hampikian G, Kan Y, Schuster GB. Long-distance charge transport in duplex DNA: The phonon-assisted polaron-like hopping mechanism. Proc Natl Acad Sci U S A. 1999;96:8353-8.

52. Núñez ME, Hall DB, Barton JK. Long-range oxidative damage to DNA: Effects of distance and sequence. Chem Biol. 1999;6:85-97.

53. Efrati E, Tocco G, Eritja R, Wilson SH, Goodman MF. "Action-at-a-distance" mutagenesis: 8-Oxo-7,8-dihydro-2'-deoxyguanosine causes base substitution errors at neighboring template sites when copied by DNA polymerase $\beta$. J Biol Chem. 1999;274:15920-6.

54. Pande P, Haraguchi $K$, Jiang $Y$ - L, Greenberg MM, Basu AK. Unlike catalyzing error-free bypass of 8-oxodGuo, DNA polymerase $\lambda$ is responsible for a significant part of Fapy $\cdot \mathrm{dG}$-induced $\mathrm{G} \rightarrow \mathrm{T}$ mutations in human cells. Biochemistry. 2015;54:1859-62.

\section{Submit your next manuscript to BioMed Central and take full advantage of:}

- Convenient online submission

- Thorough peer review

- No space constraints or color figure charges

- Immediate publication on acceptance

- Inclusion in PubMed, CAS, Scopus and Google Scholar

- Research which is freely available for redistribution 